\title{
Wpływ zagranicznych mobilności edukacyjnych na rozwój postaw przedsiębiorczych
}

DOI: $10.47050 / 65591760.266-281$

Mateusz Jeżowski, Michał Pachocki, Agnieszka Rybińska

W rozdziale przedstawione zostały wyniki badań efektów zagranicznych mobilności edukacyjnych w kontekście zdobywania kompetencji i umiejętności, które sprzyjają rozwojowi postaw przedsiębiorczych młodych ludzi. Poprzez realizację swoich celów operacyjnych europejskie programy edukacyjne nie tylko wspierają działania nastawione na rozwój umiejętności zdobywanych w ramach kształcenia formalnego, lecz także pomagają zdobyć wiele kompetencji miękkich i społecznych. Dzięki takiemu wsparciu młodzi ludzie mogą lepiej funkcjonować w społeczeństwie oraz łatwiej odnaleźć się na współczesnym rynku pracy.

\author{
Słowa kluczowe: \\ mobilność \\ postawy przedsiębiorcze \\ kompetencje kluczowe \\ europejskie projekty edukacyjne \\ program Erasmus+
}




\section{Impact of foreign educational mobility on the development of entrepreneurial attitudes}

DOI: $10.47050 / 65591760.266-281$

Mateusz Jeżowski, Michał Pachocki, Agnieszka Rybińska

The chapter presents the results of research on international mobility projects with regard to acquiring new skills and competences which support the development of entrepreneurial skills of young people. In view of their operational targets, European education programmes support activities aimed at development of skills within the formal education as well as help to acquire various "soft" and social competences. Thanks to this, young people may function better within the society and make an easier entry into the labour market.

Keywords:

mobility

entrepreneurial skills

key competences

european education projects

Erasmus+ programme 


\section{Wstęp}

Dynamika zmian na rynku pracy oznacza nie tylko zmiany na poziomie instytucji pracodawców, zmiany w środowisku pracy oraz te związane z możliwościami wykorzystania kapitału ludzkiego na rzecz lepszego rozwoju przedsiębiorstw. Naturalną konsekwencją tego procesu jest również zmiana ścieżek zawodowych oraz przejście do otwartego modelu kariery, który charakteryzuje się zdecydowanie większą elastycznością, związaną ze zmianami zawodu, pracodawcy oraz miejsca zamieszkania (Górniak i in. 2015). W kontekście powyższych wyzwań istotnego znaczenia nabiera także koncepcja uczenia się przez całe życie, która od lat 70. ub. w. na stałe zagościła w dyskusjach o jakości systemów edukacyjnych w Europie. Jednym z kluczowych elementów Strategii lizbońskiej, ogłoszonej przez UE w 2000 r., było oparcie dalszego rozwoju gospodarczego i konkurencyjności Europy na edukacji, rozumianej nie tylko jako realizacja formalnego kształcenia na poziomie instytucji, lecz także w wymiarze całożyciowego przyswajania wiedzy, w tym umiejętności podstawowych, przez osoby uczące się, bez względu na ich wiek czy poziom wykształcenia (Komisja Europejska 2000).

Od czasu wprowadzenia Strategii lizbońskiej europejskie polityki edukacyjne opierają się na katalogu ośmiu kompetencji kluczowych, które wskazano w zaleceniu Parlamentu Europejskiego i Rady z 18 grudnia 2006 r., a następnie - w wyniku konsultacji wskazujących na potrzebę zmian - zredefiniowane w Zaleceniu Rady z dnia 22 maja 2018 r. w sprawie kompetencji kluczowych w procesie uczenia się przez całe życie (Fells i in. 2018). Obok takich kompetencji jak umiejętność posługiwania się językiem ojczystym i obcym czy umiejętności matematyczne oraz techniczne wymienia się również kompetencje społeczne, obywatelskie, kompetencje w zakresie świadomości i ekspresji kulturalnej oraz kompetencje w zakresie przedsiębiorczości. O tym, że oprócz kompetencji zawodowych i doświadczenia na rynku pracy istotne są również kompetencje miękkie, świadczą także wyniki badań realizowanych w Polsce (Kocór i in. 2015). I chociaż wiedzę młode osoby wciąż zdobywają przede wszystkim w szkole, to coraz częściej korzystają również ze środków europejskich, biorąc udział w różnego rodzaju projektach o charakterze międzynarodowym.

Przyjmując za T. Rachwałem (2005), że przedsiębiorczość to zespół cech osobowości, takich jak inicjatywność, kreatywność, energia i zapał 
do pracy, wytrwałość w działaniu, a także ciekawość świata, pewność siebie i wiara we własne siły, samodyscyplina, skłonność do podejmowania wyważonego ryzyka i branie odpowiedzialności za siebie i innych, przy analizowaniu programów kształcenia formalnego warto zwrócić uwagę na ofertę europejskich programów edukacyjnych, w szczególności zaś na wyjazdy edukacyjne, które poprzez realizację swoich celów operacyjnych wspierają działania nastawione na rozwój umiejętności osób uczących się, w szczególności zaś na działania, takie jak: staże i praktyki zawodowe, wolontariat i realizacja części programów studiów oraz praktyk przez polskich studentów za granicą.

Od roku 2014 działania Komisji Europejskiej na rzecz zwiększania mobilności są kontynuowane w ramach programu Erasmus+ (2014-2020), który połączył działalność na rzecz różnych grup docelowych w poszczególnych sektorach edukacji. Projekty mobilności, takie jak wyjazdy kadry, wymiany młodzieżowe, staże, wolontariat europejski, przyczyniają się do zwiększenia wiedzy, umiejętności oraz kompetencji formalnych i pozaformalnych. Stanowią także okazję do zdobywania nowych umiejętności, rozwoju osobistego i zawodowego, a przez to do budowania kapitału ludzkiego i opartego na wiedzy społeczeństwa obywatelskiego w Polsce. Zgodnie z założeniami program Erasmus+ wspiera finansowo projekty mobilności służące podniesieniu poziomu kluczowych kompetencji i umiejętności, szczególnie tych, które są istotne dla odnalezienia się jego uczestników na rynku pracy i które mogą przyczynić się do realizacji priorytetów programu strategicznego UE na rzecz wzrostu gospodarczego, zatrudnienia, sprawiedliwości społecznej i włączenia społecznego (Komisja Europejska 2014).

\section{Szkolnictwo wyższe}

W ofercie programu Erasmus+ niezwykle istotną rolę odgrywa wsparcie na rzecz sektora szkolnictwa wyższego. Celem mobilności studentów jest przede wszystkim rozwój kompetencji interpersonalnych, społecznych i językowych oraz rozwój naukowy poprzez uczestnictwo w długoterminowych wyjazdach edukacyjnych. W 2017 r. dokonano analizy raportów indywidualnych uczestników mobilności akademickich, realizowanych w latach 2014-2015 (Dąbrowska-Resiak 2017). Raporty były obowiązkowo wypełniane przez studentów powracających do kraju z projektów mobilności. Wyniki badania pokazały, że studenci odbywający część programów studiów za granicą wysoko ocenili roz- 
wój swoich kompetencji (każda z wymienionych kompetencji została wysoko oceniona przez co najmniej 60 proc. respondentów). Wykres 1 obrazuje ocenę dokonaną przez powracających studentów, przy czym odnosi się ona do odsetka studentów, którzy udzielili odpowiedzi pozytywnej ("raczej tak" i „zdecydowanie tak") w odniesieniu do rozwoju wybranych kompetencji.

Wykres 1. Umiejętności rozwinięte podczas wyjazdu na studia i praktyki w latach 2014-2015

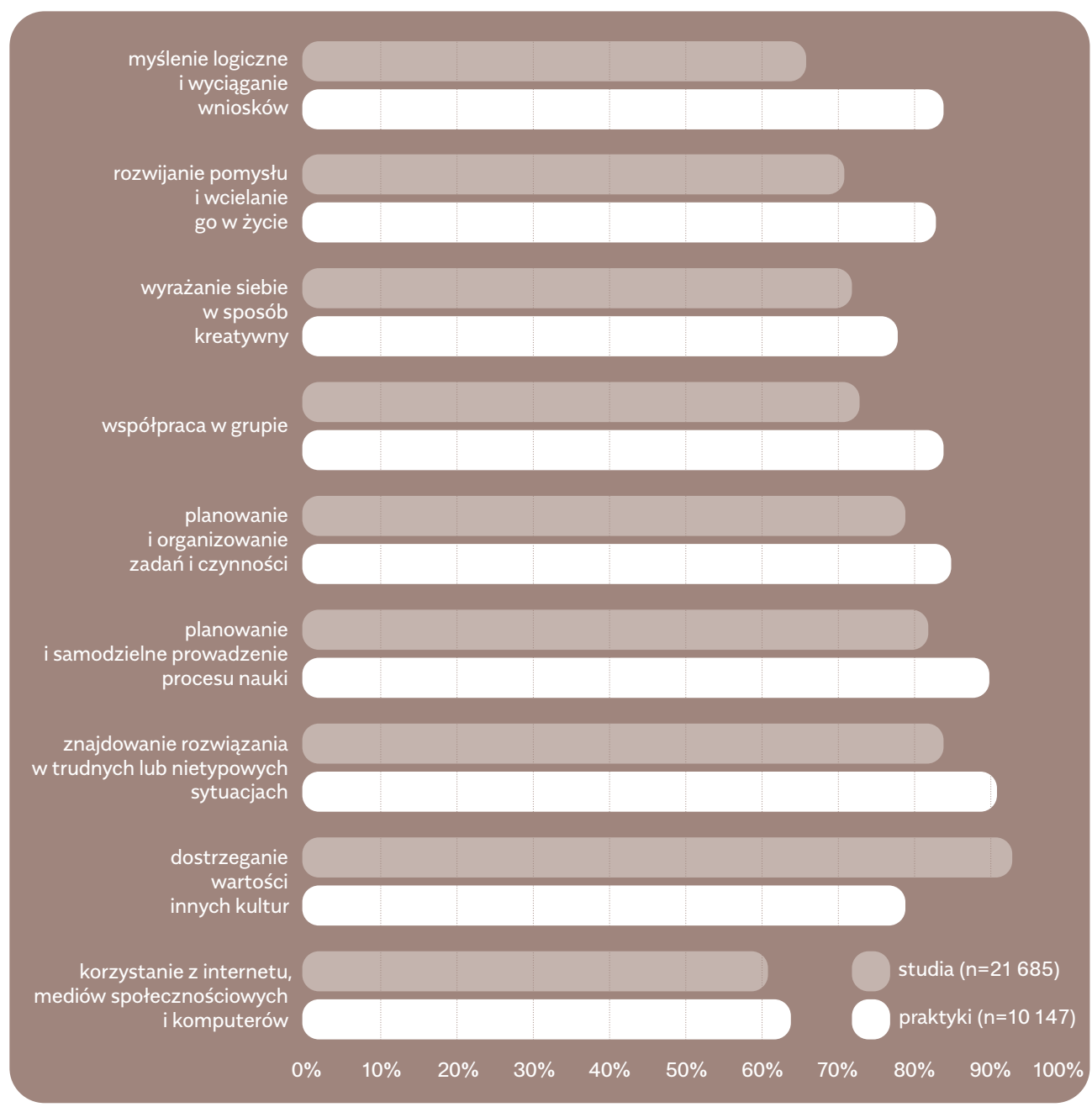

Źródło: J. Dąbrowska-Resiak, Mobilności studentów w programie Erasmus i Erasmus+.

Analiza sprawozdań studentów wyjeżdżajq̨cych w latach 2007-2015, FRSE, 2017, s. 55. 


\section{Wykres 2. Zmiany zaobserwowane przez studenta po powrocie}

\section{ze studiów i z praktykw latach 2014-2015}

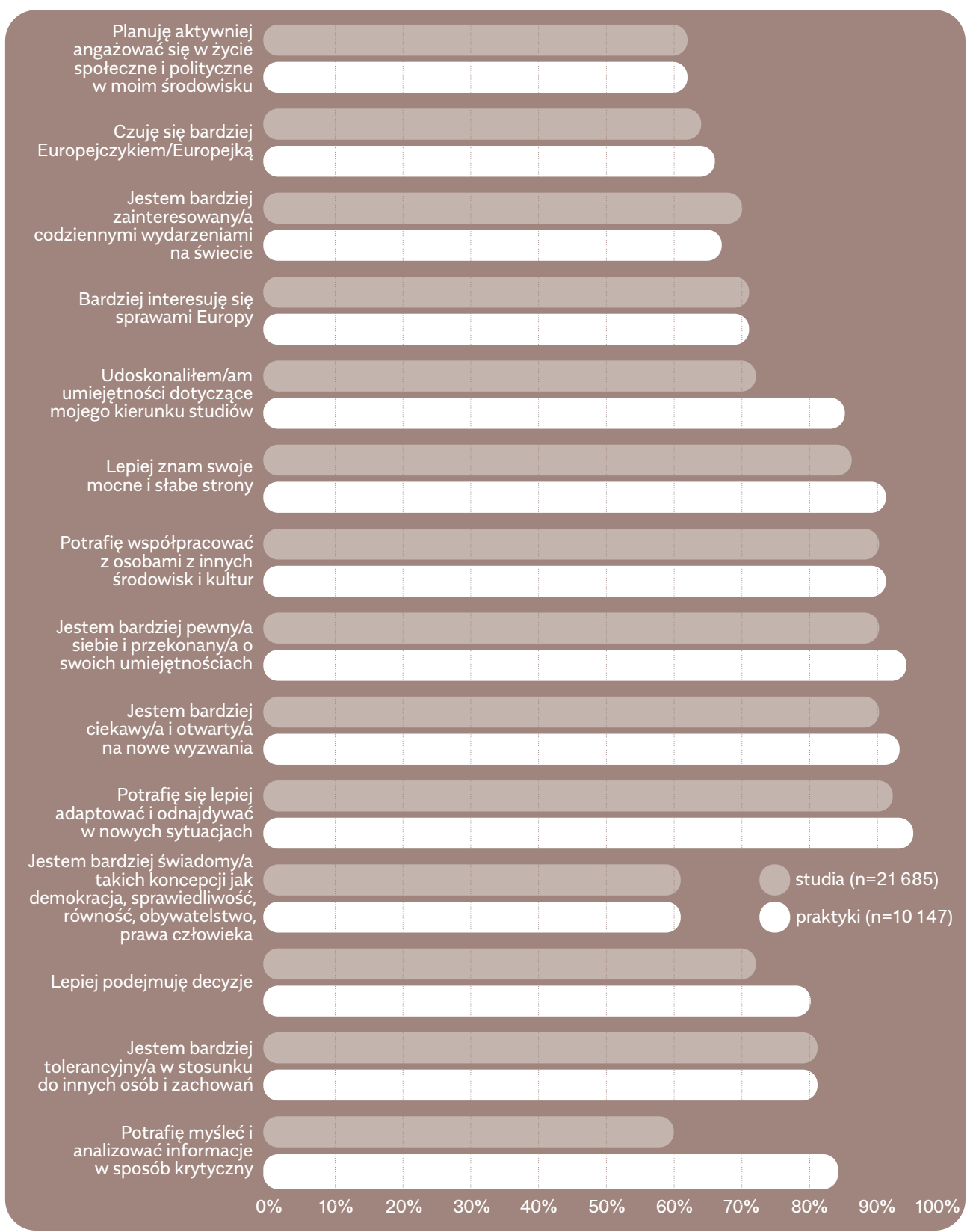

Źródło: J. Dąbrowska-Resiak, Mobilności studentów w programie Erasmus i Erasmus+.

Analiza sprawozdań studentów wyjeżdżajq̨cych w latach 2007-2015, FRSE, 2017, s. 56. 
Kompetencje, które wpływają na rozwój postaw przedsiębiorczych, zostały w miarę wysoko ocenione przez respondentów: znajdowanie rozwiązania w trudnych lub nietypowych sytuacjach (ponad 84 proc.), samoorganizacja pracy (78,5 proc.), wyrażanie siebie w sposób kreatywny czy rozwijanie pomysłu (oba ponad 70 proc.). Dodatkowo na pytanie o zmiany zaobserwowane przez studentów po powrocie ze studiów (Wykres 2) ponad 72 proc. zauważyło wzrost swoich kompetencji w zakresie decyzyjności. W przypadku grupy studentów odbywających zagraniczne staże i praktyki oceny wskazane przez nich były jeszcze wyższe w każdej z wymienionych kategorii. Prawie 91 proc. wskazało na rozwój kompetencji związanych z umiejętnością odnalezienia się w trudnych lub nietypowych sytuacjach, a 89,5 proc. na rozwinięcie kompetencji planowania i samoorganizacji zadań. Na rozwój kompetencji związanych z kreatywnością wskazało prawie 80 proc. respondentów, a z rozwojem pomysłu i jego wcielaniem w życie ponad 82 proc. Nieco wyżej grupa ta oceniła także swoją decyzyjność - ponad 80 proc. zaobserwowało pozytywną zmianę w tym zakresie. Na uwagę zasługuje również umiejętność adaptacji i odnajdowania się w nowych sytuacjach - ponad 90 proc. studentów po powrocie ze studiów i powracających z programów praktyk zaobserwowało rozwój tej umiejętności.

Ponad 6 proc. studentów wyjeżdżających na studia i 7 proc. odbywających zagraniczne praktyki lub staże odpowiedziało twierdząco na pytanie o udział w działaniach, które prowadziły do powstania innowacyjnego produktu lub odkrycia. Respondenci interpretowali owe działania bardzo szeroko - jako uczestnictwo zarówno w projektach badawczych, jak i w zajęciach dydaktycznych, w trakcie których wykorzystywano nowe metody nauczania, czy jako zdobycie inspiracji do rozpoczęcia własnej działalności gospodarczej lub rozwoju już istniejących. Mimo iż trudno jest ocenić, jak uczestnictwo w tych działaniach przełożyło się na późniejszy rozwój innowacyjnych usług lub produktów, z wypowiedzi respondentów wynika, że mieli oni możliwość bądź aktywnego zaangażowania w działania, które wpływały na rozwój kompetencji związanych z rozwojem pomysłu, bądź ich obserwacji.

\section{Edukacja zawodowa}

W 2017 r. przeprowadzone zostało badanie losów absolwentów staży i praktyk zawodowych realizowanych w ramach europejskich pro- 
gramów edukacyjnych: Leonardo da Vinci, Erasmus+ oraz projektów dofinansowanych ze środków Europejskiego Funduszu Społecznego. Wyniki badania pokazały, że dzięki doświadczeniu zagranicznej mobilności zawodowej uczestnicy mogli nie tylko zobaczyć, jak wygląda praca i praktyczna nauka zawodu w innym kraju europejskim, lecz także (często po raz pierwszy) sprawdzić się na danym stanowisku pracy. Niemal wszyscy badani uczestnicy wyjazdów zauważali, że zagraniczna mobilność wpływa na rozwój różnych kompetencji, nie tylko tych stricte zawodowych, lecz także językowych, społecznych oraz umiejętności miękkich (Wykres 3). Respondenci bardzo docenili wpływ stażu na rozwój ich umiejętności interpersonalnych. Ponad 69 proc. absolwentów staży przyznało, że doświadczenie pracy za granicą ułatwia im nawiązywanie znajomości. Dzięki wyjazdom potrafią także lepiej realizować zadania w zespołach (ponad 77 proc.) oraz pracować w międzynarodowym środowisku (ponad 74 proc.).

Wykres 3. Korzyści wynikające z realizacji zagranicznych staży

i praktyk w opinii uczestników wyjazdów

Udział w stażu za granicą pozwolił mi...

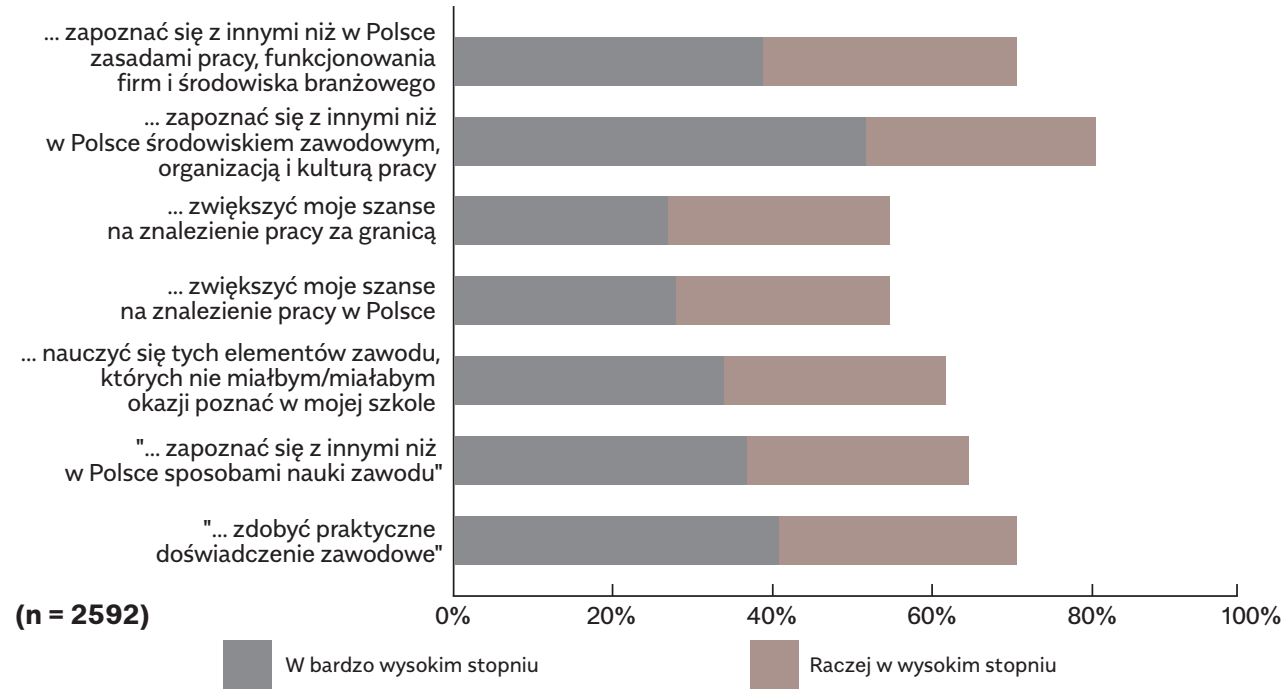

Źródło: M. Pachocki, Mobilność kluczem do kariery? Raport z badania losów uczestników zagranicznych staży i praktyk zawodowych, Fundacja Rozwoju Systemu Edukacji, Warszawa 2018. 
Większość badanych podkreślała, że udział w stażu w znacznym stopniu przyczynił się do rozwijania u nich kompetencji miękkich. Uczestnicy staży często zaznaczali, że udział w mobilności nauczył ich lepiej pokonywać stres oraz radzić sobie w trudnych i nietypowych sytuacjach. Deklarowane zmiany dotyczyły bardzo różnych aspektów, związanych m.in. z podejmowaniem inicjatywy, umiejętnością pracy w zespole czy większą otwartością. Uczestnicy badania kwestionariuszowego podkreślali, że projekty mobilności edukacyjnej miały duży wpływ na ich samodzielność. Dotyczyło to zwłaszcza wyjazdów zakładających nie tylko pracę w firmach, lecz także konieczność samodzielnego organizowania takich aspektów pobytu za granicą jak dojazd do miejsca pracy czy wyżywienie, co wymagało samokontroli i rozsądnego dysponowania środkami przyznanymi w ramach kieszonkowego. Uczestnicy badania często podkreślali również, że już sam fakt poradzenia sobie w nowych warunkach zdecydowanie wzmocnił ich pewność siebie i stawał się impulsem do podejmowania nowych inicjatyw po powrocie do kraju. Ponad połowa uczestników badania ankietowego przyznała, że udział w projektach mobilności edukacyjnej pomógł im później znajdować odpowiednie rozwiązania w trudnych i nietypowych sytuacjach (ponad 59 proc. badanych) oraz radzić sobie ze stresem (ponad 56 proc.) - wykres 4. Zdecydowana większość respondentów stwierdziła natomiast, że dzięki udziałowi w stażu nabyła umiejętność planowania i samodzielnej nauki (ponad 51 proc. badanych potwierdziło, że wpływ ten był bardzo zauważalny) oraz lepszego zarządzania czasem (ponad połowa respondentów oceniła, że wpływ stażu na tę umiejętność był zauważalny). Uczestnicy badania zwrócili także uwagę na to, że staż znacząco wpłynął na sposób organizowania ich pracy - ponad 57 proc. ankietowanych dzięki mobilności edukacyjnej nabyło umiejętność planowania i organizowania podejmowanych zadań oraz czynności. 
Wykres4. Wpływ stażu na kompetencje miękkie uczestników wyjazdów

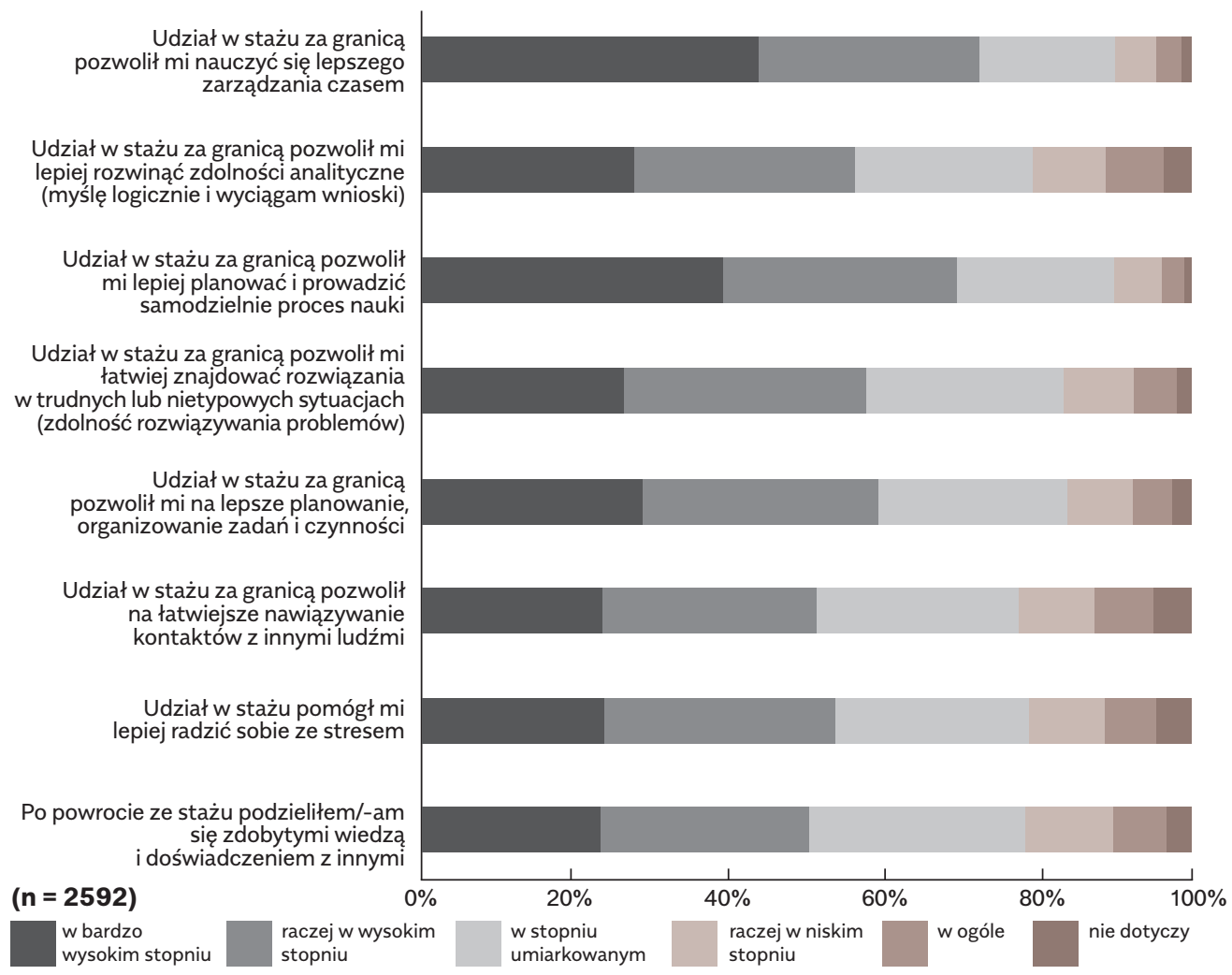

Źródło: M. Pachocki, Mobilność kluczem do kariery? Raport z badania losów uczestników zagranicznych staży i praktyk zawodowych, Fundacja Rozwoju Systemu Edukacji, Warszawa 2018.

Większość uczestników badania była zgodna, że takie wyjazdy mogą mieć również istotny wpływ zarówno na wybór dalszej ścieżki kształcenia, jak i dalsze życie zawodowe. Wyniki badania pokazały, że wśród absolwentów aktywnych na rynku pracy około 5 proc. stanowiły osoby samozatrudnione lub prowadzące własną działalność gospodarczą. Należy jednak pamiętać, że - szczególnie w przypadku młodych absolwentów szkół zawodowych - o możliwości pracy na własny rachunek często decyduje branża kształcenia, a nie jedynie kompetencje zdobyte w trakcie nauki. Warto natomiast podkreślić, że ponad 86 proc. byłych uczestników staży i praktyk zagranicznych, którzy są samozatrudnieni 
lub prowadzą inne formy działalności gospodarczej, zauważyło związek między doświadczeniem praktycznej nauki za granicą a rozwojem postaw związanych z przedsiębiorczością (Wykres 5). Jednocześnie ponad 73 proc. badanych potwierdziło zgodność tematyki stażu z obszarem obecnej działalności zawodowej.

Wykres 5. Wpływ stażu na kompetencje miękkie uczestników wyjazdów ( $n=58)$

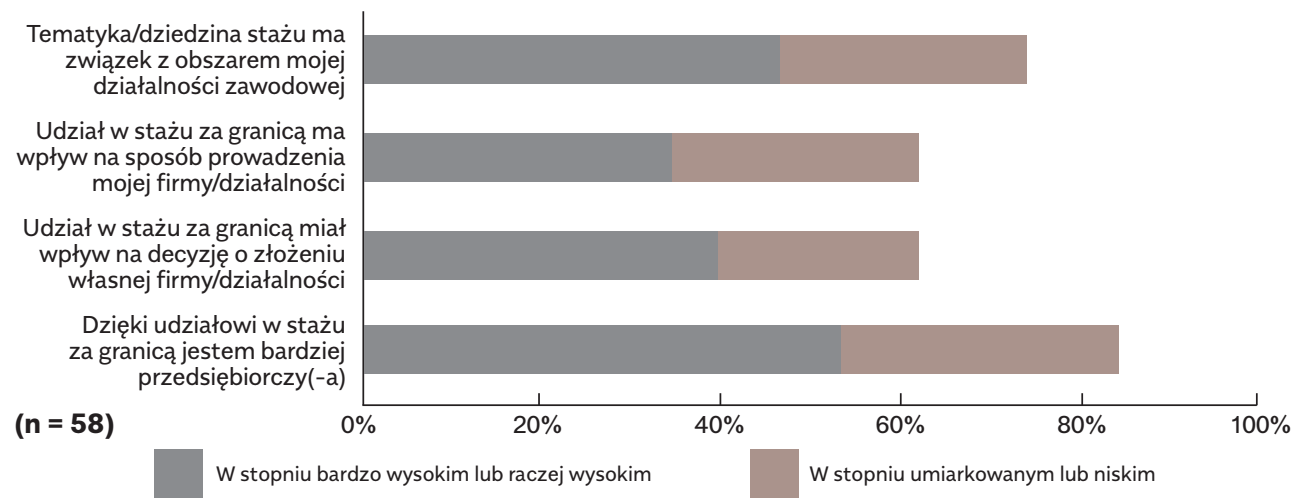

Źródło: M. Pachocki, Mobilność kluczem do kariery? Raport z badania losów uczestników zagranicznych staży i praktyk zawodowych, Fundacja Rozwoju Systemu Edukacji, Warszawa 2018.

\section{Edukacja pozaformalna}

Doświadczenia realizacji europejskich programów edukacyjnych pokazują, że na wzrost kompetencji związanych z przedsiębiorczością mają wpływ także projekty realizowane poza szkołą. O ile uczestnictwo w edukacji formalnej jest do pewnego wieku obowiązkowe i wynika zazwyczaj z motywacji zewnętrznej, o tyle edukacja pozaformalna oparta jest na dobrowolnym uczestnictwie i zależy najczęściej od wewnętrznej motywacji uczącego się. Cel nauki w edukacji formalnej jest określony odgórnie i zależy od programu nauczania, natomiast w edukacji pozaformalnej jest on określony przez osobę uczącą się. Ponadto, relacje uczących się z prowadzącymi zajęcia oparte są na odmiennych zasadach: o ile w edukacji formalnej prowadzący (nauczyciel, wykładowca) realizuje program nauczania i opiera się na zasadzie uczeń-mistrz, o tyle w edukacji pozaformalnej prowadzący zajęcia (facylitator) jest moderatorem procesu i podąża za procesem uczenia się uczestników, a re- 
lacje z nimi oparte są na zasadach partnerskich i zakładają zmienność ról: uczestnicy mogą przekazywać wiedzę facylitatorowi oraz innym uczestnikom procesu uczenia się.

Potwierdzają to badania prowadzone przez kilkanaście narodowych agencji programu Erasmus+ we współpracy z Instytutem Badań nad Edukacją Uniwersytetu w Innsbrucku. Wyniki Badania efektów uczenia się w programie Erasmus+ Młodzież (Fennes i in. 2017) pokazują, że uczestnictwo w projektach międzynarodowych opartych na zasadach edukacji pozaformalnej może prowadzić do rozwoju wielu kompetencji przydatnych w życiu zawodowym. Ponad 23 proc. ankietowanych uczestników projektów programu Erasmus+ Młodzież stwierdziło, że dzięki udziałowi w projekcie stało się bardziej przedsiębiorczymi (Wykres 6). 33 proc. zaś zadeklarowało, że polepszyły się ich umiejętności zarządzania projektem. Najczęściej deklaracje te dotyczyły uczestników projektów mobilności osób pracujących z młodzieżą i Wolontariatu Europejskiego, czyli działań, w których udział biorą starsi uczestnicy, niż np. wymian młodzieżowych. Warto zaznaczyć także, że ponad 95 proc. ankietowanych zadeklarowało, iż dzięki uczestnictwu w projekcie stało się bardziej pewnymi siebie.

Wykres 6. Które z umiejętności rozwinąłeś (rozwinęłaś) poprzez uczestnictwo w projekcie? Odsetek odpowiedzi twierdzących

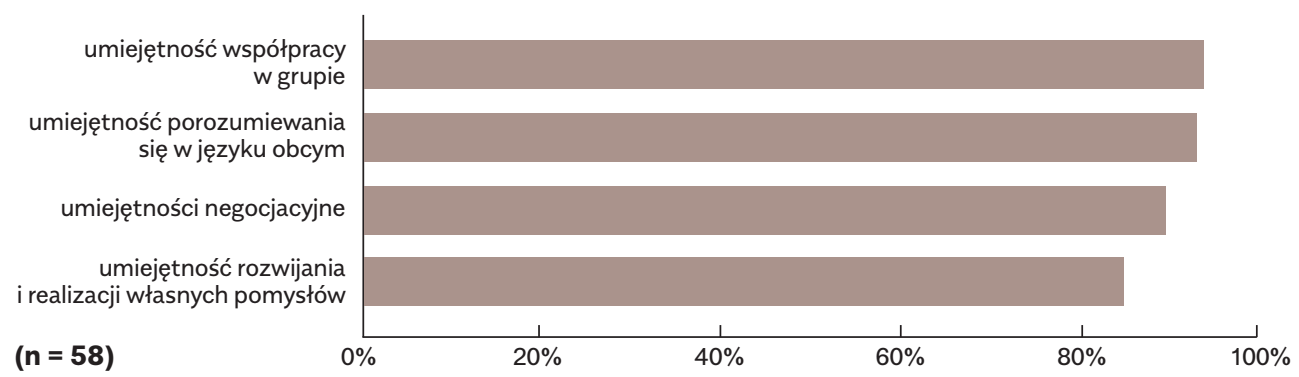

Źródło: H. Fennes, D. Bammer, A. Karsten, Exploring Erasmus+: Youth in action. Effects and outcomes of the Erasmus+: Youth in action programme from the perspective of project participants and project leaders, Institute of Educational Science, Innsbruck 2017. 
Jeśli chodzi o kompetencje związane z przedsiębiorczością rozwijane podczas projektów programu Erasmus+ Młodzież, to uczestnicy mobilności najczęściej wskazywali na: umiejętność porozumiewania się w języku obcym (93,3 proc. pozytywnych odpowiedzi), umiejętność współpracy w grupie (94,1 proc.), rozwijanie i realizację własnych pomysłów (85,2 proc.), umiejętności negocjacyjne (89,9 proc.). Tak wysoki odsetek odpowiedzi twierdzących może być spowodowany specyfiką projektów programu Erasmus+ Młodzież. Zgodnie z jego zasadami w wielu przypadkach to właśnie młodzi ludzie byli autorami i realizatorami tych działań. Ich pomysły często wynikały z własnych zainteresowań lub potrzeb lokalnej społeczności. Młodzi ludzie zaś byli odpowiedzialni za realizację projektu, począwszy od opracowania koncepcji, przygotowania i złożenia wniosku o dofinansowanie, jego realizacji, na rozliczeniu finansowym skończywszy.

Z kolei wyniki badania Kompetencje zdobywane w ramach Wolontariatu Europejskiego w kontekście wymogów rynku pracy pokazują, że ponad 94 proc. ankietowanych byłych wolontariuszy uważa wiedzę i umiejętności zdobyte podczas zagranicznego wolontariatu długoterminowego za przydatne w życiu zawodowym, a jedynie niespełna 6 proc. uznaje je za nieprzydatne. Co więcej, cenią je oni bardziej niż wiedzę zdobytą w szkole czy na uczelni, choć często podkreślają komplementarny charakter tych dwóch typów doświadczeń edukacyjnych, na przykład w odniesieniu do znajomości języka obcego, którego podstaw nauczyli się w szkole, a swoje kompetencje w tym zakresie rozwinęli podczas projektu Wolontariatu Europejskiego.

Należy także zauważyć, że aż 79 proc. ankietowanych byłych wolontariuszy posiadało doświadczenie zawodowe przed realizacją projektu wolontariatu (65,5 proc. ankietowanych z grupy 18-24 lata i 89,5 proc. z grupy $25+$ ), a ponad 81 proc. łączyło zdobywanie doświadczenia zawodowego z nauką. Warto odnotować także różnice w odpowiedziach na pytanie o przydatność kompetencji i umiejętności zdobywanych w edukacji pozaformalnej, które rysują się przy podziale na grupy wiekowe. Młodsi wolontariusze zdecydowanie częściej twierdzili, że umiejętności zdobyte dzięki uczestnictwu w projekcie Wolontariatu Europejskiego są bardzo przydatne na rynku pracy, starsi zaś wykazywali więcej rezerwy i zdecydowanie częściej odpowiadali, że umiejętności te są przydatne do pewnego stopnia. Podobnie jak w przypadku pytania o edukację formalną odsetek osób twierdzących, że kompetencje 
i umiejętności zdobywane w edukacji pozaformalnej nie są wcale przydatne, jest stosunkowo niewielki.

\section{Podsumowanie}

Przytoczone dane pokazują, że uczestnictwo w długoterminowych zagranicznych mobilnościach edukacyjnych może wpływać zarówno na rozwój wiedzy i umiejętności uczestniczących w nich młodych ludzi, jak i na kształtowanie w nich postaw przedsiębiorczych. Młodzi ludzie, uczestnicząc w tego typu projektach, stają się bardziej samodzielni, uczą się odpowiedzialności, planowania i współpracy w grupie. Mogą także w innym niż szkolne otoczeniu sprawdzić w praktyce swoją wiedzę i swoje umiejętności. Ponadto świadomość, że poradzili sobie za granicą podczas długoterminowej pracy w środowisku zbliżonym do zawodowego, sprzyja budowaniu ich pewności siebie - postawie jakże ważnej wśród przyszłych przedsiębiorców. 


\section{Bibliografia}

$\rightarrow$ Dardziński, P., Dulak, M., Jelonek, M., Kędzierski, M., Krupnik, S., Przybylski, W., Rzegocki, A., Staniłko, J.F. (2015), Przedsiębiorczość, głupcze! Jak wejść na drogę do bogactwa?, Kraków: Fundacja Lepsza Polska.

$\rightarrow$ Dąbrowska-Resiak, J. (2017), Mobilności studentów w programie Erasmus i Erasmus+. Analiza sprawozdań studentów wyjeżdżających w latach 2007-2015, www.frse.org.pl/wp-content/uploads/2017/12/Mobilności-studentów-w-progr-Erasmus-i-Erasmus_FINAL.pdf, Warszawa: FRSE.

$\rightarrow$ Erasmus+ Programme Guide. Valid as of 1 January 2014, Version 3: 09/04/2014 (2014), Brussels: European Commission.

$\rightarrow$ Górniak, J., Kocór, M., Czarnik, S., Magierowski, M., Kasparek, K., Jelonek, M., Turek, K., Worek, B. (2015), Polski rynek pracy - wyzwania i kierunki działań na podstawie badań Bilans Kapitału Ludzkiego 2010-2015, Warszawa: PARP.

$\rightarrow$ Helmut, F., Bammer, D., Karsten, A. (2017), Exploring Erasmus+: Youth in action. Effects and outcomes of the Erasmus+: Youth in action programme from the perspective of project participants and project leaders", Innsbruck: Institute of Educational Science.

$\rightarrow$ Fells, M., Płatos, B., Rybińska, A. (2018), Kompetencje kluczowe uczniów w międzynarodowych raportach i badaniach [w:] S. Kwiatkowski (red.), Kompetencje przyszłości, Warszawa: FRSE.

$\rightarrow$ Górniak, J. (red.) (2015), Polski rynek pracy - wyzwania i kierunki działań, Warszawa- Kraków: PARP.

$\rightarrow$ Jeżowski, M. (2018), Kompetencje zdobywane w ramach Wolontariatu Europejskiego w kontekście wymogów rynku pracy, Warszawa: FRSE.

$\rightarrow$ Kocór, M., Strzebońska, A., Dawid-Sawicka, M. (2015), Rynek pracy widziany oczami pracodawców. Na podstawie badań pracodawców i ofert pracy zrealizowanych w 2014 roku w ramach V edycji projektu Bilans Kapitału Ludzkiego, Warszawa: PARP. 
$\rightarrow$ Kompetencje kluczowe. Realizacja koncepcji na poziomie szkolnictwa obowiq̨zkowego (2005), Warszawa: FRSE.

$\rightarrow$ Komunikat Komisji do Rady, Parlamentu Europejskiego, Europejskiego Komitetu Ekonomiczno-Społecznego i Komitetu Regionów (2009), Bruksela: Komisja Wspólnot Europejskich.

$\rightarrow$ Pachocki, M. (2018), Mobilność kluczem do kariery? Raport z badania losów uczestników zagranicznych staży i praktyk zawodowych, Warszawa: FRSE.

$\rightarrow$ Rachwał, T. (2005), Kształtowanie postaw uczniów na lekcjach podstaw przedsiębiorczości [w:] „Przedsiębiorczość-Edukacja”, nr 1, s. 137-144.

$\rightarrow$ Rozporzq̨dzenie Parlamentu Europejskiego i Rady (UE) nr 1288/2013 z dnia 11 grudnia 2013 r. ustanawiające Erasmus+: unijny program na rzecz kształcenia, szkolenia, młodzieży i sportu oraz uchylające decyzje nr 1719/2006/ WE, 1720/2006/WE i 1298/2008/WE (2013), Parlament Europejski i Rada Unii Europejskiej, Bruksela.

$\rightarrow$ Szczucka, A., Jelonek, M. (2011), Kogo kształcq polskie szkoły, Warszawa: PARP.

$\rightarrow$ Szwałek, K. (red.), Raport 2007-2013. Programy "Uczenie się przez całe życie" oraz "Młodzież w działaniu" w Polsce (2014), Warszawa: FRSE.

$\rightarrow$ The Lisbon Strategy in short, Komisja Europejska, portal.cor.europa.eu/europe2020/Profiles/Pages/TheLisbonStrategyinshort.aspx. 